Applied Economics

\title{
Regulation and the cost of childcare
}

\section{Devon Gorry \& Diana W. Thomas}

To cite this article: Devon Gorry \& Diana W. Thomas (2017): Regulation and the cost of childcare, Applied Economics, DOI: 10.1080/00036846.2016.1276275

To link to this article: http://dx.doi.org/10.1080/00036846.2016.1276275

曲 Published online: 12 Jan 2017.

Submit your article to this journal 정

山 Article views: 30

Q View related articles $₫$

View Crossmark data 


\title{
Regulation and the cost of childcare
}

\author{
Devon Gorry and Diana W. Thomas ${ }^{\mathrm{b}}$ \\ aUtah State University, Logan, UT, USA; ${ }^{b} C r e i g h t o n$ University, Omaha, NE, USA
}

\section{ABSTRACT}

Female labour market choices depend on the availability, affordability and quality of childcare. In this article, we evaluate different regulatory measures and their effect on both the quality and the cost of childcare. First, we analyse data on regulations and costs to estimate the effect of regulatory measures on the cost of childcare. Next, we summarize the existing literature on the effect of regulation on childcare quality. We find that regulation intended to improve quality often focuses on easily observable measures of the care environment that do not necessarily affect the quality of care but that do increase the cost. Thus, we find that the regulatory environment could be improved by eliminating costly measures that do not affect quality of care.

\section{KEYWORDS}

Childcare policy; economics of regulation; regulation and business law: general

JEL CLASSIFICATION $\mathrm{L} 51 ; \mathrm{K} 20$

\section{Introduction}

Nonparental childcare options are increasingly important as female labour force participation rates continue to rise. The labour force participation rate for single women with children increased from roughly $52 \%$ in 1980 to $72 \%$ in 2009 . Similarly, the rate for married women with children rose from $54.1 \%$ in 1980 to $69.8 \%$ in $2009 .{ }^{1}$

With large numbers of women participating in the labour force, many children are spending time in nonparental care. In 2011, 61\% of children younger than five spent on average $33 \mathrm{~h}$ per week in childcare. Children with employed mothers spent on average 15 more hours in childcare than children with mothers who were not employed: $36 \mathrm{~h}$ versus $21 \mathrm{~h}$ (Laughlin 2013, figure 2).

Among children with employed mothers, those who lived below the poverty line (about 15\%) were more likely to be cared for by an unlicensed relative other than the father or grandparent (sibling or other relative) than were those who lived above the poverty line $(20.7 \%$ versus $9 \%)$. In turn, children from households living above the poverty line were more likely to be cared for by nonrelatives in a licensed day care centre, nursery or preschool (37.9\% versus $26.9 \%$ ) or a licensed family day care home, where a nonrelative cares for two or more children outside the children's home $(8.1 \%$ versus $4.3 \%)$, than were those living in households below the poverty line (Laughlin 2013, table 2).

As children spend more time in nonparental care, concerns over the quality of such out-of-home care have risen. To address those concerns, states have established licensing requirements and regulations that are intended to improve the quality of care. However, those regulations and licensing requirements are costly. In this article, we show that regulations on child-staff ratios, group size restrictions and education requirements are all associated with higher care prices.

With prices on the rise, families have to spend ever-larger shares of their income on childcare. That is especially true for low-income families. Recent data show that the cost of centre-based infant care ranges from $25 \%$ of income for a family of three living at the federal poverty level in Mississippi to $86 \%$ of income for a similar family in Massachusetts (Child Care Aware of America 2013). Childcare is a considerable part of the budget even for a family of three earning twice the federal poverty level. For centre-based infant care, it ranges from $12.7 \%$ of income in Mississippi up to $43 \%$ of family income in Massachusetts (Child Care Aware of America 2013). In the face of high costs, parents turn to informal care arrangements that include

CONTACT Diana W. Thomas dianathomas@creighton.edu C Creighton University, 2500 California Plaza, Omaha, NE 68178

${ }^{1}$ Data are from the Statistical Abstract of the 2012 Census, table 599, https://www.census.gov/compendia/statab/cats/labor_force_employment_earnings/ labor_force_status.html.

๑ 2017 Informa UK Limited, trading as Taylor \& Francis Group 
grandparents or other relatives, as well as friends, neighbours and unlicensed day care homes. Use of such informal care providers is accordingly higher among low-income and single-parent households (Brown-Lyons, Robertson, and Layzer 2001). ${ }^{2}$

For parents without those alternatives, the cost of formal childcare providers becomes the deciding factor in a family's determination about whether to rely on welfare or to seek employment. Working makes sense only if the wage that one makes in the workforce exceeds the marginal cost of childcare by more than forgone welfare received when not working. Empirical evidence suggests that all women and single mothers in particular - base their decision about whether to seek employment or to apply for welfare on the price of childcare. ${ }^{3}$ Connelly and Kimmel (2003) find, for example, that the price of childcare has a significant influence on a woman's decision to enter the labour force. More specifically, they find that a $1 \%$ increase in the price of childcare results in a decrease in employment of single mothers of between $0.3 \%$ and $1.1 \%$. They furthermore find evidence that the probability of a single mother's being a welfare recipient increases with increasing childcare costs. ${ }^{4}$ Baker, Gruber, and Mulligan (2008) find similar results with a subsidy programme in Canada. They find that when childcare is subsidized, both the use of care and the employment of women increase. If childcare is relatively cheap, a single mother might be able to earn enough income to pay for care and sustain her family. As childcare becomes more costly, single mothers are more likely to apply for welfare and stay home to care for their children. Regulatory burdens that drive up prices of childcare can therefore condemn whole sections of the population to a dependence on welfare. Even for families that keep their children in formal childcare settings, 'the economic pressures associated with poverty [and higher cost of care] impair parent psychological well-being, thereby decreasing positive parenting behaviors' (Dearing, Taylor, and Kathleen 2009, 1330).
Although families pay more, childcare providers constitute one of the lowest wage-earning groups in the country. Again, regulation intended to improve the quality of out-of-home care has been shown to be at least partially at fault. Because parents respond strongly to increases in the cost of care, childcare providers have been unable to raise prices enough to fully cover the cost of regulations when regulatory burdens have increased. Increasing regulatory compliance costs therefore results partially in lower staff wages (Blau 2007). Low wages result in high staff turnover ${ }^{5}$ and a low commitment level, which can negatively affect the quality of childcare. Concerns over differential quality and the impact of societal status on childcare outcomes therefore remain.

Federal subsidy programmes, such as the childcare tax credit, the Child Care Development Block Grant, Temporary Assistance for Needy Families and Head Start, are intended to make childcare more affordable for low-income families. Many of the state subsidy programmes are plagued with long waiting lists, however, and at best provide partial relief. Because regulation impacts how private and public funds are spent, it is imperative to take a critical look at existing regulation and its effect on price and quality. Some types of regulation might significantly affect the price of care without contributing much to quality at the same time. Identifying regulations with those unintended effects would be a first step in the right direction of providing affordable childcare to low-income families. ${ }^{6}$

In this article, we identify the most costly and least effective regulatory requirements in an effort to provide guidance for policymakers who seek to provide affordable childcare options for low-income families without compromising the quality of care. In Section 2, we estimate the relationship between different childcare regulations and the cost of care at the state level. We find that maximum child-staff ratios, group size limits and training requirements significantly increase the cost of childcare. Section 3 reviews the existing literature on the relationship

\footnotetext{
${ }^{2}$ Rigby, Ryan, and Brooks-Gunn $(2007,901)$ find that while higher regulatory teacher training requirements improve the quality of childcare, more stringent regulation overall decreases the number of children attending centre care.

${ }^{3}$ Anderson and Levine (1999) and Blau (2000a) summarize the empirical literature on the effect of child care costs on employment. Overall, the evidence suggests a strong and significant negative effect of childcare costs on women's employment.

${ }^{4}$ Previous studies on the empirical relationship between childcare costs and welfare recipience found either a small negative effect or a near-zero effect. For more information see Connelly (1990), Kimmel (1995) and Houser and Stacy (1998).

${ }^{5}$ Gormley (1990) reports that annual staff turnover rates for childcare providers are $40 \%$.

${ }^{6}$ For a systematic review of the existing literature on the effect of regulation and subsidies on quality of and access to care, see Gormley (2007).
} 
between regulatory requirements and the quality of care. The existing literature suggests that structural measures of childcare quality, such as group size limits or child-staff ratios, do not actually enhance childcare outcomes or safety, whereas other measures relating to teacher training have a positive effect on outcomes. Our analysis of costs and quality of care suggests that a number of existing regulatory requirements could be relaxed to provide cost savings to low-income families without significantly reducing the quality of childcare.

\section{Regulation and costs}

In this article, we use data on the average cost of centre-based care by state in $2012,{ }^{7}$ as well as statelevel regulation data in the same year, to measure the association between different regulatory requirements and the cost of childcare.

\section{Data and summary statistics}

Data on the regulations and cost of care come from Child Care Aware of America, the primary advocacy group for regulating childcare quality in the United States. Regulation data include information regarding mandated child-staff ratios, the presence of group size regulations, specific group size caps and education requirements for lead staff members and centre directors. Child Care Aware of America's information on the education requirements for lead staff members and centre directors distinguishes among eight different levels of educational prerequisites, ranging from less than a high school diploma to a bachelor's degree in early childhood education or a related field. To incorporate that information, we create a dummy variable, which is equal to one for states that require more than a high school diploma and equal to zero for states that require only a high school diploma or less. We also include data on income for each state to help control for state-level variation in prices that are not attributable to childcare regulations. Our final sample includes information for 50 states for 2012.

Table 1 (page 21) reports the summary statistics of the data. The average annual cost of full-time childcare for infants in centre-based childcare facilities ranges from $\$ 4,863$ in Mississippi to $\$ 16,430$ in Massachusetts, with an average of $\$ 9,466$ for all states. Full-time tuition for a four-year-old child ranges from $\$ 4,312$ in Mississippi to $\$ 12,355$ in New York. The average child-staff ratio for six-month-old infants is 4.3 children per staff member, with a low of three children per staff member in Kansas, Maryland and Massachusetts, and a high of six children per staff member in Arkansas, Georgia, Idaho, Louisiana and New Mexico. The average child-staff ratio for children four years old and older is 12.6 children per staff member, with a low of eight in New York and a high of 20 in Florida and North Carolina. The average group size limit across all states for six-month-old infants is 19.2, with a low of six infants per group in Maryland and no maximum group size requirement in 12 other states. Group size limits for children four years old and older are not regulated in many states, but where they are regulated, they range from 20 in a

Table 1. Summary statistics.

\begin{tabular}{|c|c|c|c|c|}
\hline Variable & Mean & Minimum & Maximum & SD \\
\hline Per capita income & 42,956 & 33,657 & 59,687 & 6,443 \\
\hline Infant tuition & 9,466 & 4,863 & 16,430 & 2,674 \\
\hline 4-year-old tuition & 7,635 & 4,312 & 12,355 & 1,862 \\
\hline Child-staff ratio, 6 months & 4.34 & 3 & 6 & 0.74 \\
\hline Child-staff ratio, 9 months & 4.38 & 3 & 6 & 0.78 \\
\hline Child-staff ratio, 4 years & 12.62 & 8 & 20 & 2.90 \\
\hline Group size limit, 6 months & 19.20 & 6 & No limit & 17.61 \\
\hline Group size limit, 9 months & 19.20 & 6 & No limit & 17.61 \\
\hline Group size limit, 4 years & 32.02 & 20 & No limit & 13.03 \\
\hline Required annual training (hours) & 15.10 & 0 & 40 & 6.81 \\
\hline $\begin{array}{l}\text { Minimum education requirement, } \\
\text { director }\end{array}$ & $\begin{array}{c}\text { Child Development Associate } \\
\text { Credential }\end{array}$ & $\begin{array}{l}\text { Less than high } \\
\text { school }\end{array}$ & Bachelor's degree in unrelated field & $\mathrm{n} / \mathrm{a}$ \\
\hline $\begin{array}{l}\text { Minimum education requirement, } \\
\text { lead teacher }\end{array}$ & High school diploma & $\begin{array}{l}\text { Less than high } \\
\text { school }\end{array}$ & $\begin{array}{c}\text { Bachelor's degree in early childhood education or } \\
\text { related field }\end{array}$ & $\mathrm{n} / \mathrm{a}$ \\
\hline
\end{tabular}

$\mathrm{n} / \mathrm{a}=$ not applicable.

\footnotetext{
${ }^{7}$ Results are similar if 2010 data is used. There is not much variation across years so we only present the more recent 2012 results.
} 
number of states, including Alaska, Connecticut and Illinois, to a high of 35 and 36 in Texas and Georgia, respectively.

The median education requirement for centre directors across all states is a Child Development Associate Credential, whereas lead teachers are required to have only a high school diploma (median). The states with the lowest education requirements (less than a high school diploma) for centre directors are Connecticut, Idaho, Montana and Oregon. The state with the highest education requirement for centre directors (a bachelor's degree in an unrelated field) is New Jersey. Seventeen states do not require their lead teachers in childcare centres to have a high school diploma or general equivalency diploma, whereas Rhode Island requires the highest level of education requirement for their lead teachers (a bachelor's degree in early childhood education or a related field).

\section{Results}

Table 2 analyses the relationship between different regulatory standards and the cost of childcare for infants. We ran an ordinary least squares regression using the following specification:

$$
\ln \left(\text { Cost }_{i}\right)=\beta_{0}+\beta_{1} \text { Regulations }_{i}+\varepsilon_{i}
$$

The natural log of infant childcare cost is the dependent variable, and various regulatory requirements are the independent variables. We present results for several different specifications, with different policy variables as independent variables as well as a specification that includes all the regulations together. ${ }^{8}$ In addition, we control for average state income.

The coefficients for child-staff ratios and lead staff education requirements are both economically meaningful and statistically significant across the different specifications and after controlling for income. A oneinfant increase in the child-staff ratio requirement for infants is associated with a decrease in the cost of care of between $9 \%$ and $20 \%,{ }^{9}$ which translates into a reduction in the annual cost of childcare of between $\$ 850$ and $\$ 1,890$ for the average cost of care across states. Similarly, requiring lead teachers to have a high school diploma is associated with an approximate increase in the cost of childcare of between $25 \%$ and $46 \%$, which translates into an approximate increase in the cost of care of between $\$ 2,370$ and $\$ 4,350$ per year.

The dummy variable measuring the presence of group size regulation is statistically significant for only one of the specifications reported and becomes insignificant when we control for income or childstaff ratios and lead staff education requirements. The measure for group size is statistically significant and negative across all specifications, but decreases in economic significance when we control for childstaff ratios and lead staff education requirements. The reduced magnitudes and significance are due to the fact that group size regulations are correlated with more stringent child-staff ratios and education requirements. After controlling for these factors, the

Table 2. Effect of regulation on childcare costs for infants, 2012.

\begin{tabular}{|c|c|c|c|c|c|c|c|c|}
\hline & \multicolumn{8}{|c|}{ Dependent variable: In (average annual full-time care cost) } \\
\hline & Model 1 & Model 2 & Model 3 & Model 4 & Model 5 & Model 6 & Model 7 & Model 8 \\
\hline Child-staff ratio & $\begin{array}{c}-0.229^{* * *} \\
(0.037)\end{array}$ & & & $\begin{array}{c}-0.152^{* * *} \\
(0.037)\end{array}$ & $\begin{array}{c}-0.126^{* * *} \\
(0.040)\end{array}$ & & & $\begin{array}{c}-0.098^{* *} \\
(0.041)\end{array}$ \\
\hline Group size regulations & & $\begin{array}{c}0.179^{* *} \\
(0.082)\end{array}$ & & $\begin{array}{c}0.001 \\
(0.065)\end{array}$ & & $\begin{array}{c}0.052 \\
(0.066)\end{array}$ & & $\begin{array}{c}-0.010 \\
(0.060)\end{array}$ \\
\hline Group size & & $\begin{array}{c}-0.044^{* * *} \\
(0.013)\end{array}$ & & $\begin{array}{c}-0.014^{*} \\
(0.008)\end{array}$ & & $\begin{array}{c}-0.035^{* * *} \\
(0.011)\end{array}$ & & $\begin{array}{c}-0.020^{*} \\
(0.010)\end{array}$ \\
\hline Lead staff education requirements & & & $\begin{array}{l}0.378^{* * *} \\
(0.064)\end{array}$ & $\begin{array}{l}0.305^{* * *} \\
(0.057)\end{array}$ & & & $\begin{array}{l}0.235^{* * *} \\
(0.067)\end{array}$ & $\begin{array}{l}0.225^{* * *} \\
(0.062)\end{array}$ \\
\hline Director education requirements & & & $\begin{array}{c}0.007 \\
(0.086)\end{array}$ & $\begin{array}{c}-0.036 \\
(0.074)\end{array}$ & & & $\begin{array}{c}-0.030 \\
(0.081)\end{array}$ & $\begin{array}{c}-0.047 \\
(0.073)\end{array}$ \\
\hline Control for income & No & No & No & No & Yes & Yes & Yes & Yes \\
\hline Observations & 50 & 50 & 50 & 50 & 50 & 50 & 50 & 50 \\
\hline Adjusted $R^{2}$ & 0.346 & 0.145 & 0.399 & 0.559 & 0.521 & 0.506 & 0.543 & 0.616 \\
\hline
\end{tabular}

Robust standard errors in parentheses. ${ }^{* *} p<0.01,{ }^{* *} p<0.05,{ }^{*} p<0.1$.

\footnotetext{
${ }^{8}$ All of the regressions were also run using weighted least squares, with population as the weight. The results are similar in magnitude and significance.
} ${ }^{9}$ Exact percentages are calculated as $e^{\beta}-1$. 
impact of group size alone is much smaller. This is not surprising as we would expect child-staff ratios to have a much larger effect on the cost of care than group size, since lower child-staff ratios require hiring new staff. Similarly, lead staff education requirements will result in an increase in cost of care, because being required to hire more educated staff will require centres to increase staff wages. Centres can adjust to new group size limits, on the other hand, by rearranging the layout and sizes of their classrooms, which would mitigate the effect of group size limits on the cost of care, particularly in the long run. The dummy variable measuring director education requirements is not statistically significant in any of the specifications reported.

Table 3 analyses the relationship between regulatory requirements and the cost of childcare for fouryear-old children. As for infants, the child-staff ratio requirements are statistically significant, but they are much smaller in economic magnitude. A one-child increase in the number of children per staff member for four-year-old care is associated with a reduction in the cost of childcare by only $2-4.7 \%$.

As before, education requirements for lead staff members are statistically and economically significant across the different specifications. Requiring a lead teacher to hold at least a high school degree is associated with an increase in the cost of childcare for four-year-olds of between $22 \%$ and $40 \%$. One would expect that outcome because more educated workers have higher opportunity costs in the labour market and therefore require higher wages. Those higher wages result in higher costs of care.
Of course, this analysis simply shows that childcare regulations are correlated with higher costs. They do not necessarily cause higher costs. In particular, there could be state-level heterogeneity in addition to income that is associated with both differences in costs as well as differences in regulations. In an effort to address such heterogeneity, we look at how changes in regulations across four-year-old care and infant care correlate with changes in costs across these groups. This will help address the heterogeneity issue for unobservable differences that are constant across different aged childcare. ${ }^{10}$ We use the following specification:

$$
\Delta \text { Cost }_{4 Y-I n f, i}=\beta_{0}+\beta_{1} \Delta \text { Regulations }_{4 Y-i n f, i}+\varepsilon_{i}
$$

Here the change in cost is the difference between the average costs for four-year-olds and the average costs for infants. The change in regulations represents the percentage change in group size or childstaff regulations from infant to four-year-olds.

Table 4 presents the analysis of changes across age cohorts. In the first model, we include an indicator variable for whether four-year-olds are allowed a greater group size than infants. The coefficient indicates that states who relax the group size constraints for four-year-olds relative to infants see a reduction in the cost difference of about $\$ 769$ relative to states that do not relax the group size constraint. The second model shows that a $100 \%$ increase in group size limits from infants to four-year-olds is associated with a reduction in the annual cost difference of about $\$ 317$. Thus, the more group size limits are reduced between infants and four-year-olds, the greater the

Table 3. Effect of regulation on childcare costs for four-year-olds, 2012.

\begin{tabular}{|c|c|c|c|c|c|c|c|c|}
\hline & \multicolumn{8}{|c|}{ Dependent variable: In (average annual full-time care cost) } \\
\hline & Model 1 & Model 2 & Model 3 & Model 4 & Model 5 & Model 6 & Model 7 & Model 8 \\
\hline Child-staff ratio & $\begin{array}{c}-0.048^{* * *} \\
(0.012)\end{array}$ & & & $\begin{array}{r}-0.028^{*} \\
(0.015)\end{array}$ & $\begin{array}{c}-0.024^{* *} \\
(0.010)\end{array}$ & & & $\begin{array}{c}-0.020 \\
(0.013)\end{array}$ \\
\hline Group size regulations & & $\begin{array}{c}0.129^{* *} \\
(0.059)\end{array}$ & & $\begin{array}{c}0.045 \\
(0.056)\end{array}$ & & $\begin{array}{c}0.032 \\
(0.059)\end{array}$ & & $\begin{array}{c}0.015 \\
(0.057)\end{array}$ \\
\hline Group size & & $\begin{array}{c}-0.025^{* * *} \\
(0.008)\end{array}$ & & $\begin{array}{c}-0.005 \\
(0.010)\end{array}$ & & $\begin{array}{c}-0.010 \\
(0.008)\end{array}$ & & $\begin{array}{c}-0.003 \\
(0.009)\end{array}$ \\
\hline Lead staff education requirements & & & $\begin{array}{l}0.333^{* * *} \\
(0.055)\end{array}$ & $\begin{array}{l}0.262^{* * *} \\
(0.050)\end{array}$ & & & $\begin{array}{l}0.206^{* * *} \\
(0.050)\end{array}$ & $\begin{array}{l}0.199^{* * *} \\
(0.047)\end{array}$ \\
\hline Director education requirements & & & $\begin{array}{c}-0.039 \\
(0.073)\end{array}$ & $\begin{array}{c}-0.039 \\
(0.065)\end{array}$ & & & $\begin{array}{c}-0.072 \\
(0.068)\end{array}$ & $\begin{array}{c}-0.061 \\
(0.065)\end{array}$ \\
\hline Control for income & No & No & No & No & Yes & Yes & Yes & Yes \\
\hline Observations & 50 & 50 & 50 & 50 & 50 & 50 & 50 & 50 \\
\hline Adjusted $R^{2}$ & 0.306 & 0.183 & 0.400 & 0.526 & 0.504 & 0.458 & 0.557 & 0.582 \\
\hline
\end{tabular}

Robust standard errors in parentheses. ${ }^{* *} p<0.01,{ }^{* *} p<0.05,{ }^{*} p<0.1$.

\footnotetext{
${ }^{10}$ Unfortunately, the data does not have time variation to allow for a fixed-effects analysis.
} 
Table 4. Effect of regulation changes on changes in child care costs.

\begin{tabular}{|c|c|c|c|c|c|c|c|c|}
\hline & \multicolumn{8}{|c|}{ Dependent variable: 4 year old care cost-Infant care cost } \\
\hline & Model 1 & Model 2 & Model 3 & Model 4 & Model 5 & Model 6 & Model 7 & Model 8 \\
\hline Increased Group Size & $\begin{array}{c}-768.88^{* *} \\
(316.14)\end{array}$ & & & & $\begin{array}{r}-457.75 \\
(293.52)\end{array}$ & & & \\
\hline$\%$ Change Group size regulations & & $\begin{array}{c}-316.58^{* * *} \\
(113.06)\end{array}$ & & $\begin{array}{c}-311.22^{* * *} \\
(113.16)\end{array}$ & & $\begin{array}{c}-284.79^{* * *} \\
(100.76)\end{array}$ & & $\begin{array}{c}-258.83^{* *} \\
(96.35)\end{array}$ \\
\hline$\%$ Change child-staff regulations & & & $\begin{array}{c}-175.22 \\
(227.93)\end{array}$ & $\begin{array}{c}-45.72 \\
(183.25)\end{array}$ & & & $\begin{array}{c}-325.72 \\
(198.06)\end{array}$ & $\begin{array}{c}-208.99 \\
(153.88)\end{array}$ \\
\hline Control for income & No & No & No & No & Yes & Yes & Yes & Yes \\
\hline Observations & 50 & 50 & 50 & 50 & 50 & 50 & 50 & 50 \\
\hline Adjusted $R^{2}$ & 0.083 & 0.110 & 0.009 & 0.092 & 0.269 & 0.342 & 0.273 & 0.343 \\
\hline
\end{tabular}

Robust SEs in parentheses. ${ }^{* *} p<0.01,{ }^{* *} p<0.05,{ }^{*} p<0.1$.

cost reduction between infants and four-year-olds. When we look at the change in child-staff ratios, we see that the child-staff ratio increases from infants to four-year-olds are associated with greater cost reductions as well, but the results are not statistically significant. The results are similar in column 4, which includes both variables together, and in columns 5-8, which control for state income.

\section{Regulation and quality of care}

The foregoing analysis suggests that regulation of childcare may have a significant economic effect on the cost of care. A higher cost of care may be justifiable if regulation also improves the quality of childcare. The relationship between regulation and the quality of care is more difficult to discern, however.

Existing research suggests that quality of care is particularly important in an early childhood setting, because it affects children's cognitive and social competence (NICHD ECCRN 1999, 2000). Cognitive and noncognitive skills are strong predictors of a variety of labour market and behavioural outcomes (Heckman, Stixrud, and Urzua 2006), and early childhood investments are critical for the development and accumulation of those skills (Cunha and Heckman 2007, 2008). In this section, we review the literature on the relationship between regulation and the quality of childcare to gain a better understanding of the expected effect that regulatory measures might have on the quality of care.

\section{Measuring and regulating quality of care}

The literature in child psychology measures childcare quality either for the structural characteristics of the care environment or for process features, which measure the quality of the interactions between teachers and children. ${ }^{11}$ Structural measures evaluate easily observable features of a care environment, such as group size, child-staff ratio, teacher education and training, safety, staff turnover and programme administration. Process measures, however, are more difficult to observe, because they are based on the actual interactions between the child and his or her caregiver, the programme administration and other children. ${ }^{12}$ The theoretical and empirical literature in child psychology suggests that although structural measures of quality may facilitate good interactions, process measures are more closely related to positive child outcomes and are therefore better indicators of actual quality. ${ }^{13}$

Because process quality is difficult to observe and therefore difficult to regulate, regulation is usually based on structural measures of childcare, however. Indeed, most states base their licensing requirements on specific child-staff ratios, group sizes and teacher education. Regulation will have a positive effect on outcomes as long as the structural measures of qual-

\footnotetext{
${ }^{11}$ For reviews of the literature on childcare quality, see Lamb (1998) and Love, Schochet, and Meckstroth (1996).

${ }^{12}$ Love, Schochet, and Meckstroth $(1996,5)$ characterize high process quality as follows: 'Caregivers encourage children to be actively engaged in a variety of activities; have frequent, positive interactions with children that include smiling, touching, holding, and speaking at children's eye level; promptly respond to children's questions or requests; and encourage children to talk about their experience, feelings, and ideas.'

${ }^{13}$ Existing evidence suggests that lower child-staff ratios, smaller group sizes and better caregiver education (i.e. structural measures of quality) are correlated with better child-caregiver interactions (i.e. process quality). However, cross-country evidence (Cryer et al. 1999) suggests that although many of the same structural features affect process measures of quality, identifying a particular type of structural quality measure that contributes consistently to process quality is difficult. Among the structural measures, teacher education and wages seem to be the most important (Pessanha, Aguiar, and Bairrão 2007; Phillipsen et al. 1997).
} 
ity affect development outcomes either directly or indirectly through their effect on process measures of quality.

\section{Structural quality measures and child outcomes}

The empirical literature on this topic suggests that the link between regulated structural measures of quality and child outcomes is weak at best. Scarr, Eisenberg, and Deater-Deckard (1994) show that no measures of childcare that can be regulated, except teacher wage, have any effect on observable measures of childcare quality. In a study published in the Journal of Public Health, the National Institute of Child Health and Human Development Early Child Care Research Network (Anderson and Levine 1999) concludes that the differences in children's performance that were associated with whether their centre classes met recommendations for class size, childstaff ratio, caregiver education and caregiver training were only modest.

In a meta-study of the relationship between different structural characteristics of care environment and child-specific outcomes, Blau (2001) confirms this earlier result. He finds that most existing studies fail to control for centre-specific characteristics and home inputs (i.e. family-specific characteristics). Reanalysing the data, he finds that when he relies only on within-centre variation (by comparing classrooms within each centre rather than classrooms between centres) and when he controls for home inputs, many of the structural measures of quality turn out to be both weakly related to quality and statistically insignificant. The only variable that remains important across studies after the inclusion of the relevant controls is teacher training in early childhood education. More specifically, Blau (1997, $2000 \mathrm{~b}$ ) finds that the only educational measure that consistently matters for quality care is that the caregiver has taken a college course in early childhood education in the past year. No other measure of teacher training is statistically significant or economically meaningful. Rigby, Ryan, and Brooks-Gun (2007) similarly find that while more stringent teacher training requirements improve process measures of the quality of childcare, child-staff ratios have no significant effect on process measures of the quality of care but they do reduce the number of children in centre-based care.
Mashburn et al. (2008) confirm this result in a more recent study of prekindergarten programmes. Their empirical results suggest that none of the nine structural measures of quality related to the programme infrastructure that they include in their analysis (all subjects of minimum standard of quality recommendations issued by the National Institute for Early Education Research) have a significant effect on children's development of language and academic skills during pre-K, on their social competence or on problem behaviour. Conversely, process measures that capture the quality of teacher-child interactions according to the Classroom Assessment Scoring System, a standard measure of process quality, as well as capturing child characteristics - such as race, socio-economic status and the level of the mother's education - all matter for child outcomes.

More recent studies of the relationship between quality of care and childcare outcomes usually focus on process measures of quality. The majority of such studies find that the process quality of care is an important predictor of development. Because they focus on process measures of quality, however, those studies can inform the debate on the relationship between regulation and the quality of care only to the extent that the regulated structural measures are correlated with the process measures of quality that actually affect outcomes.

\section{Structural quality and process quality}

Studies that attempt to provide an estimate of the link between structural and process measures of the quality of childcare are often used to justify regulation based on structural measures. The most comprehensive study on this link finds that while maternal caregiving is a much stronger predictor of both social and cognitive competence, among the different characteristics of the nonmaternal caregiving environment, caregiver training is a much more important input into quality than child-staff ratios (NICHD ECCRN 2002).

Burchinal et al. (2002) provide support for the idea that among the structural measures of quality, teacher training is the most effective at improving process quality. They provide evidence that the extent of both formal and informal caregiver training is associated with higher-quality care environments. In a study of Portuguese toddler childcare 
quality, Pessanha, Aguiar, and Bairrão (2007) confirm that better-paid teachers - who are usually also better educated - provide better-quality care, whereas other structural variables, such as a measure of space per child, were not statistically significant predictors of the quality of care.

Currie and Joseph Hotz (2004) analyse another dimension of quality: safety. They find that only the education of directors has any effect on the safety of children. Although having more educated directors is associated with fewer accidents, regulations on childstaff ratios and inspections have no significant effects.

\section{Unintended consequences of regulating structural measures of quality}

Our review of the literature suggests that, at best, regulation of nonmaternal childcare has a small effect on overall child development outcomes. Tighter standards have a limited ability to increase child outcomes. That finding does not mean that regulation is inappropriate for setting minimum standards for nonmaternal care.

However, because regulation increases the cost of care significantly (both statistically and economically), regulators should be mindful of the trade-off between quality and price. Mothers should not be placed in a position where the quality of their care suffers because they cannot afford nonmaternal care or because they experience financial distress from the high cost of childcare.

Blau (2007) argues that an additional unintended consequence of regulating group size limits and childstaff ratios is that they reduce staff wages at childcare centres, which may actually have a negative effect on child development, because lower wages deter the most qualified teachers from working at childcare centres and result in greater staff turnover (also associated with a lower quality of care). As previously discussed studies have shown, caregiver training is a much more important predictor of child development than group size or child-staff ratios. Regulation of the latter two aspects of childcare may therefore have a detrimental effect on the overall quality of care.

Rigby, Ryan, and Brooks-Gunn (2007) confirm these results. Using the Early Childhood Environmental Rating Scale-Revised (ECERS-R) as a measure of process quality of care for childcare centres and the Family Day Care Rating Scale (FDCRS) as a measure of process quality of care for family childcare providers, they find that while more stringent regulatory teacher training requirements improve quality of care, smaller child-to-teacher ratios have no significant effect on quality but they reduce the overall number of children in centre care.

Recent work by Hotz and Xiao (2011) provides additional evidence for the presence of unintended consequences from the regulation of childcare quality. They find that although regulation can increase the number of day care centres that are licensed and that comply with the higher standards required by private accreditation agencies, such as the National Association for the Education of Young Children, ${ }^{14}$ it also leads to a reduction in the overall availability of childcare centres, particularly in low-income markets. Hence, although regulation increases the quality of some existing centres, it forces low-income families, in particular, to resort to other types of care, such as nonrelative home-based care, which is typically found to be of lower quality than centrebased care. ${ }^{15}$ Currie and Joseph Hotz (2004) similarly note that regulation of childcare, even when it improves quality, crowds kids out into nonformal care, which tends to be less safe.

Overall, these results suggest that relaxing regulatory requirements for group size and child-staff ratios, while maintaining quality through training requirements for teachers, might lower the cost of providing childcare without significantly affecting quality. ${ }^{16}$ If one provider is allowed to care for a larger number of children, that provider can earn a

\footnotetext{
${ }^{14} \mathrm{Hotz}$ and Xiao (2011) do not look at the effects of regulation on direct quality measures.

${ }^{15}$ Being placed in lower-quality care settings can have significant detrimental effects on child development and learning outcomes, especially for children from lower-income households. Dearing, Taylor, and Kathleen $(2009,1329)$ report that 'low income was less strongly predictive of underachievement for children who had been in higher quality care than for those who had not.' O'Connell and Farran (1982) report that infants from low-income households in high-quality centre-based care demonstrate better language development than do home-reared infants from low-income households. Conversely, Melhuish et al. (1990) find that language development for infants from middle-class families was poorer when those infants were in low-quality childcare settings compared with better-quality home care. Studying the effect of day care participation on the cognitive development of 867 children from the National Longitudinal Survey, Caughy, DiPietro, and Strobino (1994) found that entering day care before the first birthday is associated with higher reading recognition scores for children from impoverished home environments.

${ }^{16} \mathrm{An}$ alternative policy recommendation to reduce the cost burden to families without affecting quality would be to provide greater subsidies for early childhood. Subsidies should also mitigate the effect the cost of childcare has on labour market outcomes for women. However, subsidies are costly to the taxpayer whereas eliminating ineffective but costly requirements could lower costs of childcare without increasing taxpayer burden.
} 
higher wage. Higher wages would attract better-educated providers and reduce staff turnover rates overall.

\section{Conclusion}

We show in this article that regulation of childcare facilities is significantly associated with the cost of care. Because female labour market choices depend importantly on the availability and affordability of childcare options, regulation should be limited and focused on variables that have the greatest possible effect on the quality of care. The literature on early childhood development, psychology and education suggests that the quality of childcare depends most importantly on the level of education of immediate care providers - that is, lead teachers and childcare centre staff. Child-staff ratios and group size limits, which are also regulated, are less effective in improving quality. They are significantly related to the cost of childcare, however, and therefore make childcare less affordable, especially for low-income families. Prudent regulatory reform should focus on deregulating those aspects of childcare that are least cost-effective.

\section{Disclosure statement}

No potential conflict of interest was reported by the authors.

\section{References}

Anderson, P. M., and P. B. Levine. 1999. "Child Care Costs and Mother's Employment Decisions." In Finding Jobs: Work and Welfare Reform, edited by D. Card and R. Blank, 420-462. New York: Russell Sage.

Baker, M., J. Gruber, and K. Milligan. 2008. "Universal Child Care, Maternal Labor Supply, and Family Well-Being.” Journal of Political Economy 116: 709-745. doi:10.1086/ 591908.

Blau, D. M. 2000a. "Child Care Subsidy Programs.” NBER Working Paper 7806, National Bureau of Economic Research, Cambridge, MA.

Blau, D. M. 2001. The Child Care Problem: An Economic Analysis. New York: Russel Sage Foundation.

Blau, D. M.. 1997. "The Production of Quality in Child Care Centers." The Journal of Human Resources 32: 354-387. doi:10.2307/146219.

Blau, D. M.. 2000b. “The Production of Quality in Child Care Centers: Another Look." Applied Developmental Science 4: 136-148. doi:10.1207/S1532480XADS0403_3.
Blau, D. M.. 2007. "Unintended Consequences of Child Care Regulations.” Labour Economics 14: 513-538. doi:10.1016/ j.labeco.2006.01.003.

Brown-Lyons, M., A. Robertson, and J. Layzer. 2001. "Kith and Kind: Informal Child Care-Highlights from Recent Research." National Center for Children in Poverty, Columbia University, New York.

Burchinal, M. R., D. Cryer, R. M. Clifford, and C. Howes. 2002. "Caregiver Training and Classroom Quality in Child Care Centers." Applied Developmental Science 6: 2-11. doi:10.1207/S1532480XADS0601_01.

Caughy, M. O., J. A. DiPietro, and D. M. Strobino. 1994. "Day-Care Participation as a Protective Factor in the Cognitive Development of Low-Income Children.” Child Development 65: 457-471. doi:10.2307/1131396.

Child Care Aware of America. 2013.Parents and the High Cost of Child Care 2013 Report. Arlington, VA: Child Care Aware of America.

Connelly, R. 1990. "The Cost of Child Care for Single Mothers: Its Effect on LFP and AFDC Participation." Discussion Paper 920-90, Institute for Research on Poverty, Madison, WI.

Connelly, R., and J. Kimmel. 2003. "The Effect of Child Care Costs on the Employment and Welfare Recipiency of Single Mothers." Southern Economic Journal 69: 498-519. doi:10.2307/1061691.

Cryer, D., W. Tietze, M. Burchinal, T. Leal, and J. Palacios. 1999. "Predicting Process Quality from Structural Quality in Preschool Programs: A Cross-Country Comparison." Early Childhood Research Quarterly 14: 339-361. doi:10.1016/S0885-2006(99)00017-4.

Cunha, F., and J. Heckman. 2007. "The Technology of Skill Formation." American Economic Review 97: 31-47. doi:10.1257/aer.97.2.31.

Cunha, F., and J. Heckman. 2008. "Formulating, Identifying and Estimating the Technology of Cognitive and Noncognitive Skill Formation." Journal of Human Resources 43: 738-782. doi:10.1353/jhr.2008.0019.

Currie, J., and V. Joseph Hotz. 2004. "Accidents Will Happen? Unintended Childhood Injuries and the Effects of Child Care Regulations." Journal of Health Economics 23: 25-59. doi:10.1016/j.jhealeco.2003.07.004.

Dearing, E., B. A. Taylor, and M. Kathleen. 2009. "Does Higher Quality Early Child Care Promote Low-Income Children's Math and Reading Achievement in Middle School?" Child Development 80: 1329-1349. doi:10.1111/ j.1467-8624.2009.01336.x.

Gormley Jr., W. T.. 2007. "Early Childhood Care and Education: Lessons and Puzzles." Journal of Policy Analysis and Management 26: 633-671. doi:10.1002/ (ISSN)1520-6688.

Gormley, W. T. 1990. "Regulating Mister Rogers' Neighborhood: The Dilemmas of Day Care Regulation." Brookings Review 8: 21-28.

Heckman, J. J., J. Stixrud, and S. Urzua. 2006. "The Effects of Cognitive and Noncognitive Abilities on Labor Market 
Outcomes and Social Behavior." Journal of Labor Economics 24: 411-482. doi:10.1086/504455.

Hotz, V. J. and M. Xiao. 2011. "The Impact of Regulations on the Supply and Quality of Care in Child Care Markets.” American Economic Review 101: 1775-1805. doi:10.1257/ aer.101.5.1775.

Houser, S., and D.-C. Stacy 1998. "The Effects of After-Tax Wages, Transfer Payments, and Child Care Expenses on Labor Market and Transfer Program Participation." Working Paper 7, Joint Center for Poverty Research, Northwestern University and University of Chicago.

Kimmel, J. 1995. "The Effectiveness of Child-Care Subsidies in Encouraging the Welfare-to-Work Transition of Low-Income Single Mothers." American Economic Review 85: 271-275.

Lamb, M. E. 1998. "Nonparental Child Care: Context, Quality, Correlates, and Consequences." In Child Psychology in Practice, edited by I. E. Sigel and K. Ann Renninger. Vol. 4. Chichester, UK: John Wiley.

Laughlin, L. 2013. Who's Minding the Kids? Child Care Arrangements: Spring 2011. Current Population Reports, US Census Bureau,Washington, DC.

Love, J. M., P. Z. Schochet, and A. L. Meckstroth. 1996. "Are They in Any Real Danger? What Research Does-and Doen't-Tell Us about Child Care Quality and Children's Well-Being." Mathematica Policy Research, Princeton, NJ.

Mashburn, A. J., R. C. Pianta, O. A. Barbarin, B. K. Donna Bryant, J. T. Hamre, M. B. Downer, D. M. Early, and C. Howes. 2008. "Measures of Classroom Quality in Prekindergarten and Children's Development of Academic Language, and Social Skills." Child Development 79: 732-749. doi:10.1111/j.1467-8624.2008.01154.x.

Melhuish, E. C., E. Lloyd, S. Martin, and A. Mooney. 1990. "Type of Childcare at 18 Months?II. Relations with Cognitive and Language Development." Journal of Child Psychology and Psychiatry and Allied Disciplines 31: 861870. doi:10.1111/jcpp.1990.31.issue-6.

NICHD ECCRN (National Institute of Child Health and Human Development Early Child Care Research
Network). 1999. "Child Outcomes When Child Care Center Classes Meet Recommended Standards for Quality. NICHD Early Child Care Research Network." American Journal of Public Health 89: 1072-1077. doi:10.2105/AJPH.89.7.1072.

NICHD ECCRN (National Institute of Child Health and Human Development Early Child Care Research Network). 2000. "The Relation of Child Care to Cognitive and Language Development." Child Development 71: 960-980. doi:10.1111/14678624.00202.

NICHD ECCRN (National Institute of Child Health and Human Development Early Child Care Research Network). 2002. "Child-Care Structure -> Process -> Outcome: Direct and Indirect Effects of Child-Care Quality on Young children's Development." Psychological Science 13: 199-206. doi:10.1111/1467-9280.00438.

O'Connell, J. C., and D. C. Farran. 1982. "Effects of Day-Care Experience on the Use of Intentional Communicative Behaviors in a Sample of Socioeconomically Depressed Infants." Developmental Psychology 18: 22-29. doi:10.1037/0012-1649.18.1.22.

Pessanha, M., C. Aguiar, and J. Bairrão. 2007. "Influence of Structural Features on Portuguese Toddler Child Care Quality." Early Childhood Research Quarterly 22: 204214. doi:10.1016/j.ecresq.2007.02.003.

Phillipsen, L. C., M. R. Burchinal, C. Howes, and D. Cryer. 1997. "The Prediction of Process Quality from Structural Features of Child Care." Early Childhood Research Quarterly 12: 281-303. doi:10.1016/S0885-2006(97) 90004-1.

Rigby, E., R. M. Ryan, and J. Brooks-Gunn. 2007. "Child Care Quality in Different State Policy Contexts." Journal of Policy Analysis and Management 26: 887-908. doi:10.1002/(ISSN)1520-6688.

Scarr, S., M. Eisenberg, and K. Deater-Deckard. 1994. "Measurement of Quality in Child Care Centers." Early Childhood Research Quarterly 9: 131-151. doi:10.1016/ 0885-2006(94)90002-7. 